\title{
Plant biotechnology at NRC, Egypt: ongoing research and future plan

\author{
Mahmoud M Sakr
}

Address: Center of Excellence for Advanced Sciences (CEAS), Genetic Engineering and Biotechnology Division, National Research Center (NRC), Egypt

from 2009 American University in Cairo Research Conference

Cairo, Egypt. 5 April 2009

Published: I July 2009

BMC Proceedings 2009, 3(Suppl 3):O4

This abstract is available from: http://www.biomedcentral.com/I753-656I/3/S3/O4

(c) 2009 Sakr; licensee BioMed Central Ltd.

The history of plant biotechnology research at National Research Center (NRC) of Egypt dates back to late eighties, when the Genetic Engineering and Biotechnology Research Division (GEBRD) was established. The mission of the division is to conduct basic and applied research in plant, animal, microbial and medical biotechnology. Recently, in the framework of on going reforming policy of $S$ \&T sector in Egypt, a new component called Center of Excellence for Advanced Sciences (CEAS), dedicated to biotechnology, nanotechnology and renewable energy research was launched. A pilot unit for the application of genetic engineering and biotechnology was also established to help in the scaling up and process development of biotechnology-based products. Salient achievements of the biotechnology research at NRC include development and production of some diagnostic kits (peroxidase and urease), diagnostic techniques (triplet PCR for HCV detection), laboratory kits (plasmid DNA isolation kit), Biopesticides and Biofertilizers (Bt \& Biomold), Virus-free potato seeds, tissue culture plants (banana, date palm \& ornamental plants), transgenic plants (potato and faba bean) and candidate antitumor and antiviral molecules and compounds (RIP and Cucurbitcean). The publication rate of the biotechnology research at NRC is about 100 manuscripts in international journals per year. The current biotechnology research at NRC are focusing on biotechnology-based production of pharmaceutically bioactive substances and molecules, biopesticides, transgenic plants resistant to biotic and abiotic stresses and mapping of disease resistance genes. Future plan is focusing on bioethanol and biofuel production, improvement of neglected drought tolerance crops (drought, sorghum, flax and date palm) and effective and better utilization of native valuable genetic resources. 